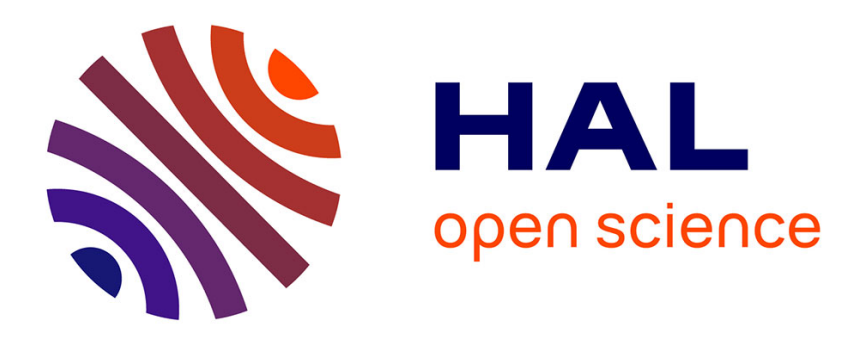

\title{
Political Ideology and Economic Growth: Evidence from the French Democracy
}

François Facchini, Mickaël Melki

\section{To cite this version:}

François Facchini, Mickaël Melki. Political Ideology and Economic Growth: Evidence from the French Democracy. 2013. halshs-00917617

\section{HAL Id: halshs-00917617 https://shs.hal.science/halshs-00917617}

Submitted on 12 Dec 2013

HAL is a multi-disciplinary open access archive for the deposit and dissemination of scientific research documents, whether they are published or not. The documents may come from teaching and research institutions in France or abroad, or from public or private research centers.
L'archive ouverte pluridisciplinaire HAL, est destinée au dépôt et à la diffusion de documents scientifiques de niveau recherche, publiés ou non, émanant des établissements d'enseignement et de recherche français ou étrangers, des laboratoires publics ou privés. 


\section{Documents de Travail du Centre d'Economie de la Sorbonne}

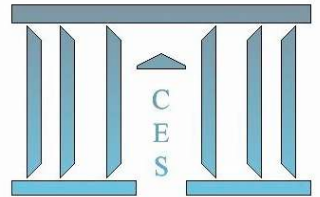

Political Ideology and Economic Growth:

Evidence from the French Democracy

François FACCHINI, Mickael MELKI

2013.77

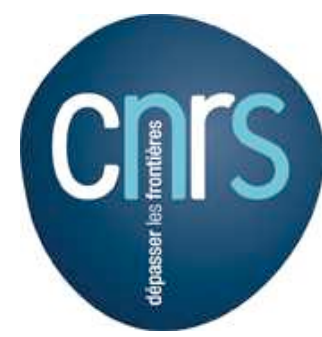




\title{
Political Ideology and Economic Growth:
}

\section{Evidence from the French Democracy}

\author{
François Facchini $^{\mathrm{a}}$, Mickael Melki ${ }^{\mathrm{b}}$
}

\begin{abstract}
${ }^{a}$ University of Paris-Sud, Faculté Jean Monnet, 54 Bd. Desgranges, 92330 Sceaux, France. Phone: +33-614-407-8114. E-mail facchini@univ-paris1.fr

b University of Paris 1 Sorbonne, Centre d'Economie de la Sorbonne, 106-112 Bd. de L'Hôpital, 75647 Paris cedex 13, France. Phone: +33-614-407-8323. E-mail mickael.melki@,univ-paris1.fr
\end{abstract}

\begin{abstract}
We provide a test of the impact of voters' political ideology on economic growth and of the role of preferences for government size as a transmission channel. We focus on France from the beginning of its stable democratic experience in 1871. A move of voters' ideology to the right increases economic growth over the total observation period. However, the growth effect of ideology is mediated by voters' preferences for government size only during the post-World War II period. For reverse causality concerns, we use the political ideology of other historical democracies as an instrument variable for France's ideology.
\end{abstract}

Résumé. Nous testons l'impact de l'idéologie politique des électeurs sur la croissance économique. Nous étudions également le rôle des dépenses publiques comme canal de transmission entre idéologie et croissance. Nous nous concentrons sur l'ensemble de l'expérience démocratique française qui se consolide à partir de 1871. Nous trouvons qu'un déplacement de l'idéologie des électeurs à droite augmente la croissance économique sur l'ensemble de la période d'observation. Nous trouvons aussi que l'effet de l'idéologie sur la croissance passe par les préférences des électeurs en matière de dépenses publiques uniquement après la Seconde Guerre Mondiale. Pour traiter les problèmes d'endogénéité, nous instrumentons l'idéologie politique de la France par l'idéologie d'autres démocraties historiques.

Keywords. Political Ideology; Economic Growth; Public Spending.

Mots clés. Idéologie politique; Croissance économique; Dépenses publiques.

JEL Classification. E6, O43, H11 


\section{Introduction}

For a few years, the literature has focused increasingly on the economic consequences of individuals' social norms, such as social capita and trust. ${ }^{1}$ However, other essential dimensions of social norms such as individuals' political ideology have received less attention. This seems even more surprising that the influence of partisan effect on various policies has been studied extensively. ${ }^{2}$ This lack of interest in the growth effect of political ideology may stem from the fact that political ideology is commonly assumed to affect the business cycle, and not the long-term trend of economic growth. Indeed, as Alesina (1987) argues theoretically, the government's political ideology is supposed to affect short-term economic fluctuations through the citizens' expectations and not through persistent social norms. ${ }^{3}$ However, the institutional economics literature argues that ideology plays an essential role in long run performance through the individual behaviours and the public political choices (North 1998; 1990). Indeed, individuals' ideology can directly affect growth through their norms regarding labour and saving behaviour. Voters' ideology can also work indirectly on growth through the policies for which they vote. ${ }^{4}$

In this paper, we ask whether and how variations in voters' ideology, measured by the political affiliation of the parliament according to the right-left divide, have played a role in explaining economic growth. We investigate this question with time-series data on France for

\footnotetext{
${ }^{1}$ See Durlauf (2002); Zak and Knack (2001); Beugelsdijk, De Groot and Van Schaik (2004).

${ }^{2}$ See Imbeau, Pétry and Lamari (2001) for a meta-analysis on the effects of political ideology on various policies.

${ }^{3}$ Concerning the empirical literature, Alesina (1988) shows that in the United States, Democrats perform better during the early years of the term, as they implement monetary and expansionist budget policies not expected immediately by voters. Alesina, Roubini and Cohen (1997) confirm this finding with OECD panel data for the period 1960-1993. In this line, recent works show that governments' political ideology by itself matters for the expectations of financial markets (Snowberg et al. 2007) and for private consumption (Gerber and Huber 2009).

${ }^{4}$ Both effects are, of course, closely related, since the policies resulting from the electoral choices stem, at least partially, from the voters' norms.
} 
the period 1871-2004, covering the whole of the French democratic experience. We focus on France because it is the first country in Europe to have implemented universal male suffrage in 1848, with a parliament elected democratically on a continuous basis from the establishment of the 3rd Republic in 1871. Furthermore, as the right-left divide originated in France with the Revolution of 1789, this ideological divide has been deeply rooted in French political life from as early as 1871. Consequently, we use the composition of the Lower Chamber of the parliament, elected by universal (male) suffrage throughout the observation period, as a main ideology index, according to the right-left divide of the times. ${ }^{5}$ This enables us to have a big picture of the ideological orientation of a society in a given time period. The purpose of the paper is also to investigate the transmission policy channels through which ideology impacts growth. As voters' ideology may be regarded as the society's choice concerning the appropriate level of government interference in the economy, we focus here on the size of government as a possible transmission mechanism between ideology and growth; the size of government corresponding to the total public spending as a percentage of GDP.

The theoretical literature exploring the ideological long-term effects with equilibrium consequences is scarce. In line with Piketty (1995) and Benabou and Ok (1998), Benabou (2008) argues theoretically that societies can embrace ideologies, leading to equilibrium associated with inappropriate public responses to market failures. In his model, citizens can adopt an inefficient leftist ideology, voting for an excessively large government or a laissezfaire ideology, with blind faith in an invisible hand. Bjørnskov (2005) provides a theoretical framework supporting the fact that people with a strong merit assumption (thinking that inequality is fair and expecting high returns for effort) are more productive, and thus foster economic performance directly. In addition, people with such an assumption vote for rightwing parties promising stronger legal systems, thus boosting economic growth indirectly.

\footnotetext{
${ }^{5}$ In France, the voting franchise was extended to women in 1944.
} 
Among the scant empirical evidence of an ideological effect on growth, Bjørnskov (2005) initially uses OECD data for the period 1970-2000, to show that countries to the right of the average experience more growth, especially thanks to better legal systems and less government intervention. Accordingly, Bjørnskov (2008) provides evidence that the higher the income inequalities are, the more a government shift to a right-wing ideology improves growth. In contrast, Osterloh (2012), using OECD data for recent periods, provides evidence for the absence of growth effect of an aggregated index of ideology. However, he shows that parties with preferences corresponding to market intervention and welfare state policies impact negatively on growth. Most of the empirical research on the effects of political ideology has in common the use of time-varying ideology indexes, based on the party's manifesto. In this regard, our paper differs from the existing literature in that we study the effect of ideology measured by the actual composition of the parliament, according to the right-left divide of the times. We do not need here to associate a certain group of parties (left or right) with certain sets of policies. Indeed, in all bi-party democracies, one can clearly identify a right and a left at any period of time, while it is impossible to define ex ante the content of a right-wing (or left-wing) policy.

To the extent that voting behaviour is a proxy for voters' social norms, the level of government intervention in the economy resulting from the voters' choice is an ideal candidate for the study of transmission mechanisms between ideology and growth. While the endogeneous growth theories provide useful predictions regarding the growth effect of government intervention, ${ }^{6}$ literature on the relationship between voters' ideology and the scope of government is scarce. Indeed, the intuitively positive effect of leftwing ideology on

\footnotetext{
${ }^{6}$ While excessive government intervention is typically found to be detrimental to growth (Barro 1991), investment in protection of property rights leads to higher growth (De Haan and Sturm 2000). However, redistribution can reduce the private incentive to accumulate capital and to invest. On the other hand, public investment, creating positive incentives for the private sector, has a positive effect on growth, as documented by the empirical literature (Romp and De Haan 2007).
} 
the size of government has not received strong empirical support in more recent empirical literature $^{7}$. Using time-series US data from 1929, Kau and Rubin (2002) find that a move of the Senate's ideology towards the left has little impact on government size. (Pickering and Rockey $(2011 ; 2012)$ (PR hereafter) argue that this unclear effect is due to the fact that prior research examines an unconditional relationship between ideology and government size. They argue that theoretically the effect of political ideology is tempered by income and found empirical support with panel data for OECD countries (PR 2011) and the US States (PR 2012) in post-1960 periods. According to their model, when incomes are low, the pain of taxation in terms of lost utility from reduced private consumption is high. Even if the ideological climate is statist (that is, left wing), the median voter with low income will not tolerate large increases in taxes. However, as income grows, statist inclinations may be indulged. In this paper, we empirically revisit this assumption with a much longer time horizon, in which one can reasonably expect profound changes in voters' ideology and income.

By investigating the growth-ideology relationship, this paper is also related inevitably to the literature studying the effects of economic fluctuations on policy sentiments; i.e. voting along a left-right axis (see Durr 1993; Stevenson 2001; Markussen 2008). This literature claims consistently that policy sentiments shift leftwards when the economy is prospering, and to the right during recessions. This leads us to take seriously the identification issue between political ideology and economic growth. Until now, the empirical literature has not provided appropriate instrumental variables for political ideology, as acknowledged by Bjørnskov (2008). ${ }^{8}$ In this paper, we propose to instrument the French political ideology with

\footnotetext{
${ }^{7}$ Prior empirical research did not find a clear positive effect of a leftist ideology on the size of government (see the literature survey of PR 2011).

${ }^{8}$ The only exception is (Bjørnskov and Potrafke 2011) who use government employment as an instrument to study the effect of ideology on economic freedom, but this approach is not appropriate for our study. Indeed, the Wagner law assumes that as a society becomes more developed, the proportion of public spending in total output tends to rise.
} 
the lagged US and UK political ideology. This strategy is based on the hypothesis that a country's political choice can be influenced by the experiences and choices of other countries (Quinn 2003; Quinn and Toyoda 2007; Buera et al. 2011).

Our time series-analysis, covering 130 years, departs from the existing literature studying the effects of political ideology. Indeed, the literature is composed mainly of cross-sectional studies that focus on a group of countries or regions inside a country. As a consequence, we avoid the main difficulties inherent in these studies. The first one stems from fairly short observation periods that generally do not exceed 25 years (Potrafke 2011). The second one is related to the delicate measure of the cross-national differences of the right- and left-wing ideologies. ${ }^{9}$ In their meta-analysis, Imbeau et al. (2001) notice that partisan effects would be too subtle to ensure sufficient robustness of cross-sectional statistical estimations. However, our long period entails another problem; that is, the time-consistency of an ideology index covering 130 years. While manifesto-based ideology indexes have the advantage of accounting for the time-varying ideology, our index does not capture the fact that right- and left-wing ideologies have, undoubtedly, evolved through time. However, we cope with this issue by allowing our index to have different effects in different periods. For this, we use interactions between our ideology index and time dummies, for periods in which one could reasonably expect the ideological divide to have changed. In this view, our approach is complementary to the research based on manifesto indexes, and provides additional insights on the topic.

In this paper, we provide empirical support that right-wing majorities in parliament, approximating voters' ideology, experience more economic growth than left-wing majorities, throughout the period 1871-2004. The long-term effect of a switch from a totally left-wing

\footnotetext{
${ }^{9}$ For instance, using the Database Political Institutions (DPI) (Beck et al. 2001), the ideology index of shows suspiciously that France was perceptibly more right-wing than the US, between 1975 and 2000 (Bjørnskov 2005, 144).
} 
parliament to a totally right-wing one is a $1.20 \%$ increase in the GDP growth rate. The growth effect of political ideology is robust when splitting the sample period into two subperiods, before and after World War II. The use of Granger causality and 2SLS methods makes us confident that the flaw of causality is running from political ideology to economic growth. We find evidence that government intervention in the economy, approximated by government size, is the transmission channel through which ideology impacts growth for the post-World War II period, but not for the pre-war period. This is line with the finding that as the voters' mean income rises, a move of their ideology to the left increases the size of government. Far from denying the evolution of the right and the left since 1871 , we thus provide evidence that the rightwing ideology approximated by the composition of the parliament corresponds to preferences for smaller government sizes in the post-1945 period but for bigger ones in the pre-1945 period.

The paper is structured as follows. Section 2 presents the data and the empirical strategy. Section 3 presents the results. Section 4 concludes.

\section{Data}

\subsection{The Ideology Indexes in the Literature}

The empirical research on the growth effect of political ideology provides some measure of ideology, based mainly on the parties' manifesto. Bjørnskov (2005; 2008) employs the categorization by Beck et al. (2001), based on the parties' names and platforms. ${ }^{10}$ Like numerous research on the effects of political ideology, the index used by Osterloh (2012) comes from the Manifesto Research Group (MRG) data of Budge et al. (2001). Based on the content analysis of party manifestos, the MRG data provides an index for each party according to numerous policy issues, identifying time-variant party preferences. Given that

\footnotetext{
${ }^{10}$ Beck et al. (2001) define the largest government party according to whether they have a left-wing, centrist or right-wing political orientation.
} 
the political platforms of the parties evolved through time, a right-wing (/left-wing) party of the 1940 s can be classified by the MRG as more left-wing (/right-wing) than a left-wing (/right-wing) party of the 2000s. For instance, according to the MRG data, the right-wing party, Union for a Popular Movement (UMP), of 2007, is as left-wing as the Socialist Party (SIFO) of 1946, and more left-wing than the Communist Party (PCF) of the early 1950s. This classification has, admittedly, the advantage of accounting for the time-varying ideology of parties, but disregards the real political divide that structured the political landscape of a country at any point of time.

Moreover, the construction of such manifesto-based indexes require ex-ante assumptions on what right-wing and left-wing policies are. As a consequence, the endogeneous construction of these indexes allows the study a priori the transmission channels between ideology and growth. However, we seek here to determine these channels a posteriori, with an ideology index independent of its potential channels. Under the assumption that the MRG data reflects properly the parties' preferences for specific policies, research on the growth effects of this index studies the economic performance of some policies, placing the focus on ideology as secondary. ${ }^{11}$

\subsection{Building an Ideology Index for France since 1870}

First, a measure of ideology makes sense only if elections are democratic so that voters can reveal their true preferences. The French case provides one of the longest stable democratic periods since the establishment of the $3^{\text {rd }}$ Republic $(1870-1940)$, which was interrupted briefly by the Vichy regime (1940-1945) during World War II. For these reasons, our study

\footnotetext{
${ }^{11}$ One cannot totally discard the hypothesis that manifestos are strategically written texts, which possibly so not reflect the party's ideology. However, the empirical literature supports that, for at least some dimensions, policy preferences of governments, derived from party manifestos, are correlated with policy actions after the election (see for instance Quinn and Toyoda 2007). In this context, research on the effects of such an index comes to studying the ability of the index to explain the actual political choices.
} 
starts in 1871, the date of the Constituent Assembly election, and excludes the non-democratic Vichy period ${ }^{12}$. We also exclude the World War I period that corresponds to an unusual situation gathering of both right- and left-wing parties in the Union Sacrée government. Given that the Lower Chamber of the parliament is the sole political institution elected by universal (male) suffrage throughout the period 1871-2004, our ideology index focuses on the composition of this Chamber, the Chamber of Deputies, during the $3^{\text {rd }}$ Republic (1870-1940), the National Assembly during the $4^{\text {th }}$ Republic (1946-1958), and the $5^{\text {th }}$ Republic $(1958-$ present). ${ }^{13}$ In this regard, our index reflects the voters' political ideology that is expressed democratically.

Another important prerequisite for the building of an ideology index is the existence and permanence of a right-left ideological divide. First, as the right-left divide originates in France in the wake of the French Revolution, this divide is already firmly established, and structured the political landscape in 1870 France. Second, contrary to other historical democracies such as the US and the UK, the social issue appeared at the end of the $19^{\text {th }}$ century with socialist parties in the French political spectrum, and has remained a touchstone of French politics (Goguel 1946; Candar and Becker 2004). By contrast, looking at the UK, for example, the Labour party was alleged to have links with the Russian communists in the 1920s, while New Labour can even be considered to be more right-wing than the Tories of the 1930s (Cusack et al. 2010). However, the permanence of the divide in France throughout our period has been

\footnotetext{
${ }^{12}$ The regime was only really established in 1875 , with the adoption of the Wallon Amendement (constitutional bill) and the constitutional laws. The National Assembly was, and still is split into two chambers: an Upper one, the Senate, and a Lower one, the House of Deputies, which is the sole institution elected by direct universal suffrage.

${ }^{13}$ An additional reason to focus on the Lower Chamber is that the $3^{\text {rd }}$ Republic leaves almost no room for the executive power, being qualified as the "Republic of Deputies"(Goguel 1946). This bi-camera system characterizes the functioning of the French democracy until now, with the exception of the Vichy Regime. The 4th Republic (1946-1958) followed upon the previous one with roughly the same institutions, but under the 5th Republic (1958-nowadays), the Parliament is composed of the Senate and the National Assembly, which became the Lower Chamber.
} 
subject to much debate among historians and analysts of French political life. ${ }^{14}$ It appears from this debate that two trends have cohabitated all through the French democratic experience: on the one hand, the variety and the diversity of the political groups and parties; and, on the other hand, the dualism of the fundamental (right-left) tendencies (Goguel 1946, 19). Historians such as Siegfried (1930) provide striking examples of stability in the voting patterns, and of the relative weight of the two main tendencies, since 1871. Although no one can deny that this divide has evolved through time, it seems to have been permanently structured by certain economic issues, such as public spending and public debt.

As an example, in 1871, left and right were already opposed about debt, owing to the costs of the war against Prussia (1870-1871), La Commune (1871) and the colonial strategy (Fridenson 2005, 587; Candar and Becker 2004, 313). As early as the 1870s, and especially since the Waldeck-Rousseau government (1899-1902), the left developed its main issues, such as the regulation of working time and working conditions, wealth redistribution through tax and the denunciation of the mur de l'argent ("wall of money") ${ }^{15}$ (Duclert 2005, 211). Even though some left-wing governments, such as the Bloc des gauches ("Coalition of the Left") (1899-1902) and the Combes government (1902-1905) can be presented as socially shy (Candar and Becker 2004, 223), all main laws on the labour market (minimum wage, working time regulation and, more generally, labour market entrance and exit conditions) were adopted by left majorities in parliament. The left also seems to have been rather in favour of nationalization of certain strategic public sectors, redistributive policies likely to decrease inequalities (Fridenson 2005, 589-592).

\footnotetext{
${ }^{14}$ While some analysts of the French political life, such as Aron (1957) and Rémond (1963), deny a connection among the rights and the lefts, they acknowledge that the tendency among historians is to underpin the thesis of a continuity, or the gist of the lefts and the rights through time (Rémond 1963, 13-23). Boy and Mayer (1997, 15) argue that the left-right divide seems to remain a touchstone of the French political landscape.

${ }^{15}$ Expression referring to the opposition, in the 1920s, of the banking and financial circles to any economic and social reforms in France.
} 
However, the continuity of this divide is not that obvious, especially in the early years of the $3^{\text {rd }}$ Republic. Indeed, until the Ralliement ("Rallying") of the Church to the republican regime in 1898 , the main ideological opposition was between a republican left in favour of a republican regime and secularization, and a conservative right supporting a monarchist and religious government system. More generally, we need to take into account in our analysis potential evolutions of the French right-left divide, provoked by institutional changes such as this one.

Within this context, we build an ideology index measuring the parliament's political ideology on a yearly basis since 1871. This index is a continuous variable, indicating the percentage of right-wing seats in the Lower Chamber. It is distributed between 0 and 1: 0 reflecting the absence of right-wing deputies; and 1, a chamber totally filled with right-wing deputies. An immediate difficulty comes from the identification of the affiliation of a given party, especially as some of them, mostly from the left, have moved from the extreme left to the centre-right over decades. To classify the various majorities, we use several sources provided by historians (see Appendix, Table 10). As the moderate parties participated in the formation of the majorities, and were active inside these, they are assigned the affiliation of the government to which they belonged. Additionally, we do not include in our index the few independent deputies, the "Non-Inscrits", after having verified that their presence would not influence the colour of the majority. Furthermore, for the data on election years, during which the majority in the parliament may shift, we consider the composition of the outgoing Chamber; that is to say, the percentage of right-wing deputies before the election. Figure 1 presents the index. Left-wing parties governed for 79 years, as compared to 55 years for rightwing ones. The mean of the index is 0.44 , showing that the parliament is slightly more leftwing during the observation period, and the standard deviation is 0.21 . 
For our identification strategy, we build ideology indexes for the US and the UK, by following the same methodology. For the US, the ideology index represents the percentage of Republican members in the House of Representatives, given that the political spectrum is composed basically of the Republican and the Democrat parties during our observation period. For the UK, the ideology index provides the percentage of seats held by the Conservatives and their allies when they formed a coalition in the House of Commons. ${ }^{16}$ The indexes are presented in Figure 1, and the sources are presented in Appendix.

Because of the rawness of our ideology index, it is important to verify to what extent results obtained with alternative measures of ideology differ. For this, we first construct a dummy variable, coded 1 when the majority in the Lower Chamber is right-wing and 0 otherwise. While this alternative measure provides general information on the parliament's affiliation, our main index seems more suitable for studying the policy channels from ideology to growth. Indeed, as most bills are voted on by a qualified majority, our main index, measuring the size of the majority, can capture the fact that a strong majority could more easily implement its favourite policies, and thus strengthening its growth effect. Second, as in reality there are substantial lags between preferences (as expressed in the ideology index) and policy enacted by government, so we also use a moving average of the previous ten years in our main index. Such a measure of ideology also provides a better proxy for the persistence of voters' ideology. Finally, for comparison, we use an ideology index based on data coming from the Manifesto Reasearch group (MRG) data of (Budge et al., 2001). This data is

\footnotetext{
${ }^{16}$ The index for the UK ideology considers the seats held only by the Conservative party for the periods 1868 1885, 1922-1951 and 1974-2005; the Conservative party and the Liberal Unionist party for the period 18891918; the Conservative party and the Unionist party for the periods 1955-1959 and 1970; the Conservative party and various allies for the period 1964-1966.
} 
available for the period 1946-1997. Following PR (2011), annual series are constructed for the median voter ideology position, by weighting party ideologies according to their vote received. This is measured from -100 to +100 , so that -100 is extreme left and 100 is extreme right.

\subsection{Specification Issues}

In the following, all variables are considered in logarithm so that the first differences approximate their growth rates. The dependent variable is the growth rate of real GDP, from Maddison's website. ${ }^{17}$ Figure 2 depicts the data. To our knowledge, Maddison's data is believed to be the most reliable source among the long-term data available for the French GDP. ${ }^{18}$

\section{$* * *$ Insert figure 2 here***}

The time-series literature. investigating the growth effect of government, established a set of typical and useful variables. Based on a Cobb-Douglas production function, developed by Ram (1986), growth models commonly include the share of investment in real GDP, labour force, openness of the economy and the share of government expenditure in real GDP. In our empirical analysis, investment is given by the gross domestic capital formation as a percentage of GDP, and the main source used is Maddison's website. ${ }^{19}$ The labour force represents the average annual hours actually worked, provided mainly by Cette, Kocoglu, and Mairesse (2009). Openness is the percentage of the sum of importations and exportations in

\footnotetext{
${ }^{17}$ http://www.ggdc.net/MADDISON/oriindex.htm

${ }^{18}$ A comparison with the series provided by Toutain (1997), available from 1890, shows that the two series are highly and positively correlated, as expected.

${ }^{19} \mathrm{http}: / /$ www.ggdc.net/MADDISON/oriindex.htm
} 
total GDP, and is provided by Asselain and Blancheton (2005). The size of government measures the total public spending (central state, social protection and local public authorities) as a share of GDP, and is constructed by linking Delorme and André (1983) and the series of the National Institute of Statistics and Economic Studies (INSEE). ${ }^{20}$ All variables used in this analysis are described extensively in Table 10, in the Appendix.

Except for government size, we estimate these variables in log-first differences, which make the series stationary and enable us to avoid any concerns of spurious regressions, with variables integrated of different orders. Indeed, it is an established result in the growth literature that these variables are stationary in first differences (for an extensive analysis of the stationarity of the series, see Facchini and Melki 2013). While these variables generally enter the regressions in growth rates or in first differences in time-series analyses, the literature is divided on whether government size should enter the regression in level or in growth rate. Although Ram (1986) argues theoretically for the use of the first difference of government size in the growth models, he acknowledges that specifications can include the variable in level, as initially done by Landau (1983). However, the use of government size in level, along with variables in first difference that are stationary or I(0), can produce spurious regressions if government size is not I(0). Mittnik and Neumann (2003) justify the use of the level government size in time-series regressions by the fact that although unit root tests may support the hypothesis of non-stationarity, this variable cannot be integrated of order one, I(1), since it is somewhere between 0 and 1, by definition. Among others using time-series data $^{21}$ Kocherlakota and Yi (1996) derive certain time-series properties implied by endogeneous growth theories, arguing for the use of government size in level in the growth models. One implication is that temporary changes in government policies can have temporary effects on output growth, but permanent effects on output levels.

\footnotetext{
${ }^{20}$ To construct this series, we followed Facchini and Melki (2013) and Florio and Colautti (2005).

${ }^{21}$ See for instance Jones (1995); Evans (1997); Kocherlakota and Yi (1997).
} 
Our purpose being to investigate the long-term growth effect of government, our model includes government size in level. However, as government size is an ideal candidate as a transmission channel between ideology and output growth, the presence of this variable in the specification could hide the potential indirect effect of ideology on growth. Thus our baseline specification excludes government size and includes investment, labour, openness and the oil price that is an important control for external shocks, especially for the post-Second War period (Perron 1989). ${ }^{22}$ We also estimate a second specification, including our ideology index in level, into the baseline specification. Then, to perform a miniature sensitivity check of the impact of ideology, and to explore the transmission mechanisms, we include government size along with the ideology index into the baseline specification. Finally, the lagged dependant variable is included systematically as a regressor, because of the possible persistence in economic growth, and problems of serial autocorrelation. Given the presence of the lagged dependent variable in the specification, the estimates provide the current period (or shortterm) impact of government size and ideology. The long-term effect of these variables can be calculated by multiplying the point estimate by $1 /(1-b)$, where $b$ is the point estimate of the lagged dependent variable.

\subsection{Structural Breaks}

A concern inherent in time-series analyses, especially covering a period of more than one century, is the possible structural break in our model. With the same data as used in this paper, Facchini and Melki (2013) explore this issue extensively. They show that the year 1945 is a natural structural break, for both the French real output and government size. They also provide evidence of a non-monotonic relationship between government size and real output. A consequence for the present analysis is that the relationship between ideology, government

\footnotetext{
${ }^{22}$ Indeed, Perron (1989) showed the importance of the oil shocks in the trend of US output.
} 
size and output growth may have evolved over time. To take into account the possible structural breaks in the relationship investigated, we employ three different methods. First, we re-estimate our model including time dummies. A dummy for the post-World War II period is included, as well as dummies for the three different Republics, covering our observation periods. Indeed, one can reasonably expect the institutional setting inherent in each Republic to have played a role. A second way of investigating the changing effect of political ideology on growth is to add interactions between ideology and time dummies, in which one can expect that the political beliefs may have changed. Such changes can be a result of changes in legal and political institutions, which we capture with time dummies for each of the three Republics. A last solution that we use consists of splitting the whole observation period into pre- and post-war periods, and re-estimating our model for these subperiods.

\subsection{Reverse Causality Bias}

A final concern is that ideology may be determined endogeneously. Indeed, ideology may have deep cultural determinants, such as historical, legal or sociological factors. However, such variables are, in large part, highly persistent, and the analysis here controls for the (political) institutions. As a robustness check, we estimate a specification, including sociodemographic variables that are likely to influence both growth and ideology. Moreover, our inclusion of the lagged dependent variable further mitigates these concerns. However, ideology can also be influenced by short-term economic fluctuations, as illustrated by Markussen (2008). Indeed, he argues that the median voter's ideology shifts leftwards when the economy is prospering, because when he feels that he is getting richer, he also demands more insurance. We employ two strategies to cope with this issue. Following PR (2011), the use of the 10-year moving average of our ideology index can lessen concerns about endogeneity, since the ideology measure substantially predates the observations of output 
growth. However, this kind of Granger causality does not imply true causality, because it remains possible that a third dynamic drives both ideology and economic growth. As a consequence, we also adopt a 2SLS estimation of our model. We propose to instrument ideology in France with the lagged political ideology of the other democratic countries throughout the $20^{\text {th }}$ century, the US and the UK.

This approach relies on the assumption that own and foreign countries' past experiences influence a country's policy choices. First, this external influence can be explained by a learning process from the political leaders (State-centred approach), or from the citizens (society-centred approach). Leaders and citizens observe and reproduce the successful political choices of other countries. In line with the State-centred approach, Buera et al. (2011) argue theoretically and empirically with panel data, over the post-1950 period, that neighbours' past experiences influence countries' market-oriented policies. Testing both approaches, Quinn and Toyoda (2007) provided evidence that economic openness policies are determined by both global and domestic ideology for the post-1950 period. Second, the imitation can also be explained by the transfer of knowledge between countries, through the movement of populations, and the links between the economic and political elites. Third, foreign political experiences can have the effect of lending credibility to certain policies among voters and political leaders of a country. That is developed extensively by the policy transfer literature (Dolowitz and Marsh 2006). Finally, the imitation process can be explained by the structural dependence among countries. This dependence can be imposed by leading economies, or by the geographic proximity with other countries. Using data covering the $20^{\text {th }}$ century, Quinn (2003) finds that geographic proximity entails the convergence of financial liberalization policies, through close trade relations and competitive policy emulation.

All these imitation effects are all the stronger as the countries are culturally closed to each other. We focus on the US and the UK because of their common democratic experience with 
France since the end of the $19^{\text {th }}$ century. Indeed, the UK adopted the nearly universal male suffrage in 1884 , and completed this democratization process in 1918 . With regard to the US, while the Voting Rights Act extended the voting franchise to all minorities in 1965, the country can be considered to have nearly universal suffrage since the late $19^{\text {th }}$ century. The cultural proximity also comes from the links between the economic and political elites of these countries. For instance, the evolution of the French left towards la Deuxième Gauche ("the Second Left") ${ }^{23}$ in the 1950s, is admittedly explained by the exile to the US of a number of left-wing French leaders (Jean-Pierre 2000).

These two countries also have the advantage of being the world's leading economies and France's major trade partners. As the economies of the three countries are closely connected, they face similar problems and can be led to modify their ideologies and political choices at the same time. Moreover, as the US and the UK have been the leading economies since the end of the nineteenth century, their economic experiences, such as economic crises, can have delayed effects on other economies, such as the French one. For instance, the effect of the 1929 crisis was delayed and progressive in France, in contrast with the other countries. In such a case, voters and political leaders can learn from the US and the UK's responses to crises before revising their political preferences and choices. As an example, the American and British pro-market experiences, in the early 1980s, influenced change of the French right towards the free-market in 1986. The right-wing party, Rally for the Republic (RPR), proposed clear neoliberal reforms, inspired by the election of Margaret Thatcher in the UK, in 1979, and Ronald Reagan in the US, in 1980 (Baudouin 1990). The innovation of such a platform and the interest in the Anglo-Saxon experiences contributed to the electoral success of the French right at that time.

\footnotetext{
${ }^{23}$ La Deuxième Gauche ("the Second Left") was born in response to the centralised and Marxist tradition of the French left, and based on trade unions and non-governmental organisations.
} 
Therefore, in line with Quinn and Toyoda (2007) who use the electoral support for Communist parties worldwide as indicative of global ideology, we assume that the electoral support for right-wing parties in the US and the UK, throughout the $20^{\text {th }}$ century, have influenced the electoral support for right-wing parties in France. Our instrument is given by the mean of the US and the UK ideology indexes. However, it is not impossible that the French model have influenced the Anglo-Saxon democracies in the $20^{\text {th }}$ century. To overcome the possibility of reverse causality between the French and the US-UK ideologies, we use as instruments the lags of the US-UK ideologies. The lag length is determined by the information criteria.

\section{Results}

\subsection{Ideology and Economic Growth}

At first sight, the French economic growth seems to be higher under the legislature, with a right-wing majority in the parliament over the period 1871-2004. In fact, on average, the growth rate under a right-wing majority at the Lower Chamber is almost $4 \%$, while it is $2.4 \%$ under a left-wing one. However, this insight needs to be tested empirically, to conclude on its robustness. Consequently, we estimate the effect of ideology in a standard set-up for the whole sample period 1873-2004. Column 1 of Table 1 reports the results of estimating the baseline model without political ideology or government size, which deserves a few comments. First of all, the growth rate of the investment share and openness are statistically significant and positive, which conforms to standard assumptions. However, the variations in labour and oil price never attain significance. The absence of effect of the labour variable is not an unusual result in the literature (see for instance Roy 2009). Moreover, it is unlikely that oil prices affected the French economic growth before World War II, which explains the absence of the significance of oil price in this battery of tests. Despite these reservations, the 
model does a good job explaining annual growth performance, as the fit and explanatory power is satisfactory.

\author{
***Insert Table 1 here***
}

Turning to the question of the paper, political ideology indeed seems to contribute to growth. In column 2 , the coefficient of ideology is statistically significant at $5 \%$, which can be considered more than satisfactory given the crudeness of the measure. Although little emphasis should be put on the size of the estimate, it suggests that a right-wing ideology has a positive and statistical significant effect on economic growth. Given the presence of the lagged dependent variable, the parameter estimates reflect the current period (or short-term) impact on economic growth of the explanatory variables. Thus the impact of ideology on the long-term steady-state level of growth can be calculated from the coefficient of the lagged dependent variable, and yields the coefficient 0.012 . To interpret this coefficient, consider an archetypal parliament full of left-wing deputies, compared to an archetypal parliament full of right-wing deputies. If we take the switch from an archetypically left-wing parliament to an archetypically right-wing one, then the long-term impact of this switch is an increase in the GDP growth rate of $1.20 \%$, all else being equal.

As a comparison, we run the same regression with alternative measures of ideology. Column 3 shows that the dummy variable of ideology, right dummy, does not reach any reasonable level of significance. This implies that, more than the mere affiliation of the parliament's majority, the size of the majority matters. This can also suggest that the growth effects of ideology are mediated by policies voted for in the parliament. Column 4 presents the estimate results when using the 10-year moving average of our main measure of ideology. Taking the average of the past ten years of data helps to lessen concerns about endogeneity; 
the ideology measures now predate the observations on economic growth substantially. With such a measure, the magnitude and significance of ideology is even strengthened, compared to our main index. This result gives credence to the use of the moving average, and in some sense establishes Granger causality from ideology to economic growth; that is, ideology has forecasting power for predicting subsequent changes in the economic growth rate, but not vice versa. This also supports the hypothesis that the ideology effect is a long-term one, through persistent social norms.

\subsection{Transmission Channel}

We now conduct a series of sensitivity checks on the effect of ideology on growth. The first check consists of investigating the role of government size, as a transmission channel mediating the growth effect of ideology. If government size were a transmission channel, including this variable in the specification along with ideology would remove the impact of ideology on growth. The estimate results are presented in Table 2. As shown in column 1, the estimated coefficient of government size does not reach significance. Furthermore, the inclusion if this variable increases the magnitude and significance of the ideology variable. This seems to support the fact that public spending is not the expected transmission channel.

However, we can reasonably expect the relationship between government and economic growth to have evolved over more than one century. Facchini and Melki (2013) found a nonlinear relationship between government size and output in France over the $20^{\text {th }}$ century. They also showed that World War II was a structural break in this relationship. Consequently, column 2 of Table 2 shows the estimate results of the last specification, when including a dummy for the post-World War II period. Government size turns out to be negative and significant at the $1 \%$ level. This tends to confirm the changing growth effect of government size over our sample period. However, the impact of right ideology is robust, thus supporting 
the fact that government size is not a channel for the whole period. Another source of bias could come from structural breaks or omitted variables inherent to institutions. The change in Republics entails a change in legal and political institutions, thus potentially influencing the ideology-growth relationship. However, controlling for the Republics, as shown in column 3, provides the same conclusion as the specification of column 2. This suggests a stable relationship between ideology and growth over the sample period.

\section{***Insert Table 2 here***}

\subsection{Robustness Checks and Stability Tests}

It is possible that the effect of ideology on growth is mediated by omitted variables or, that ideology is simply a proxy for another determinant of growth. If this turns out to be true, then the estimated coefficient of ideology should be weaker and less significant when introducing such variables. In his model explaining political ideology, Markussen (2008) provides a broad set of socio-economic variables affecting ideology, which can also potentially affect economic growth: immigration, dependency ratio, union density, union bargaining, selfemployment, education, life expectancy. As a robustness check, we introduce these variables in our specification. In the absence of historical data on union density and union bargaining, we use a variable of strike intensity, measuring the number of individual non-worked days in a year, on the assumption that non-worked days increase with union power. Furthermore, we introduce additional variables that are likely to be correlated with both ideology and economic growth, such as unemployment, inflation and the electoral years. Unemployment and inflation represent alternative channels through which ideology may influence growth. We also introduce a dummy variable, coded 1 for the electoral years, to check if the growth effect of our index of ideology merely reflects a political business cycle provoked by the arrival of a 
new government. Each new variable is added to the set of control variables of the baseline specification and dummies for republic, in a separate regression, in order to keep degrees of freedom at a reasonable level, and to avoid concerns of multicolinearity. As shown in Table 3, the size and significance level of the coefficient of ideology remain remarkably stable across specifications. This confirms the positive relationship between right ideology and economic growth, when different economic covariates are taken into account.

\section{***Insert Table 3 here***}

We now focus on the stability of the relationship between ideology and economic growth. A way of tackling this issue consists of estimating the effects of interaction variables between our ideology index and time dummies. Table 4 displays the estimated coefficients of the interaction terms. The specification of column 1 of Table 4 includes interaction terms between our ideology index and dummies for each Republic, representing potential changes in the French right-left divide. We find here a positive and significant effect of the interactions variables for the $3^{\text {rd }}$ and the $5^{\text {th }}$ Republics, while the interaction with the $4^{\text {th }}$ Republic does not reach statistical significance. As the $4^{\text {th }}$ Republic represents only a decade in a sample period of 130 years, we can be rather confident in the stability of the effect of ideology on growth. Furthermore, the $3^{\text {rd }}$ Republic covering 70 years, one can expect the right-left divide to have evolved over this period and, consequently, the ideology-growth relationship. Like 1898, the ralliement corresponds to a significant change in the right-left divide, from religious to economic issues, so we divide the $3^{\text {rd }}$ Republic into two subperiods, 1873-1898 and 18991939. Column 2 of Table 4 presents the estimates results with interaction terms between right ideology and dummy 1873-1898 and dummy 1899-1939. The effect of ideology turns out to be stable over the $3^{\text {rd }}$ Republic. Regarding the transmission mechanism, including government 
size into the specification of column 1 alters the qualitative results regarding the interaction terms. Indeed, the interaction term with the $5^{\text {th }}$ Republic is no longer significant, while the interaction with the $4^{\text {th }}$ Republic reaches the $10 \%$ significance level, and is negative. This suggests that government size could be a relevant transmission channel for the post-war period, especially during the $5^{\text {th }}$ Republic.

\section{***Insert Table 4 here***}

\subsection{Tackling the Reverse Causality Bias}

As noted above, a potential concern in this analysis is that ideology may be endogeneous. This concern can be mitigated by previous evidence of Granger causality from ideology to growth, and by evidence of the robustness of the impact of ideology to the introduction of various alternative determinants of growth, and competitive variables for ideology. However, at this stage of the analysis, no causality statement would be reasonable.

We now use the lagged ideology index for the US-UK ideology, as an instrument for ideology in France. Table 5 presents the estimation of the first-stage regression. The French ideology is regressed on the lagged US-UK ideology, the exogeneous variables of our baseline growth regression, the lagged growth and the lagged French ideology. Indeed, Fair (1970; 1984, 210-214) showed that, in autroregressive models, all the lagged left- and right hand-side variables must be included in the instrument list to obtain consistent estimates. The lag length for the US-UK ideology is 3 , according to the information criteria. However, as the contemporaneous and the first lag of US-UK ideology do not reach significance, they are excluded from the regression. As outlined in Table 5, coefficients on the lagged US-UK ideology induce variations in the French ideology. Though signs of the coefficients are of mixed magnitudes, this presupposes the existence of causality from US-UK ideology to the 
French ideology. Moreover, the first-stage F-statistics suggest that our instruments are strong (Stock and Yogo 2005). Table 6, column 2 presents the second stage of the 2SLS estimates. We notice that the coefficient of right ideology is unchanged compared to the OLS estimates. This makes us confident of the absence of reverse causality bias. ${ }^{24}$

***Insert Tables 5 and 6 here***

To make sure of the exogeneity of our instrument, we conduct a falsification test in which we regress the French ideology in year $\mathrm{t}$ on contemporaneous and future US-UK ideology, in years $t, t+1, t+2, t+3$ and $t+4$. The estimate results are shown in Table 11, in the Appendix. The results of this falsification test show that present and future US-UK ideology has no effect on French ideology in year t. This provides evidence that the US-UK ideology does Granger-cause the French ideology, while the French ideology does not Granger-cause the US-UK ideology.

\subsection{Subperiods}

We now turn to the analysis of the growth-ideology relationship for the pre- and postWorld War II subperiods. Table 7 provides the estimate results for the pre-war period, 18731938. The baseline specification does not include oil price, as that is not relevant for this subperiod. Column 1 shows that the influence of right ideology is positive and statistically significant at the $1 \%$ level. When including both variables in the model, as shown in column 2 , the effect of ideology is robust, while government size does not reach any reasonable level

\footnotetext{
${ }^{24}$ To test for endogeneity, we also perform a Hausman test. In an unreported test, we include the predicted value of the error term of the first-stage regression in the baseline growth equation, along with the ideology variable and the other independent variables. Since the predicted values are not significant $(\mathrm{p}=0.63)$, the endogeneity assumption can be rejected.
} 
of significance. This set of regressions supports our previous finding of a growth effect of ideology that is not mediated by the public spending channel for this period.

\section{***Insert Table 7 here***}

Table 8 provides the estimates results for the post-war period, 1947-2004. When ideology without government size is included in the baseline specification, column 1 shows that it has a positive and significant influence on output growth. For comparison purposes, we run the same regression with alternative measures of ideology. For this subperiod, the dummy variable of ideology has a positive effect, and reaches the 5\% significance level (column 2 ). However, when using the manifesto-based index, built from the MRG data available for the period 1947-1997, ideology does not impact growth (column 3). This justifies the use of our index of ideology, that does not associate a priori the right and the left with typical policies, whose effects can have evolved though time. When interacting our main ideology index with the dummies for the $4^{\text {th }}$ and the $5^{\text {th }}$ Republics, we again find the significant and positive effect of right ideology for the $5^{\text {th }}$ Republic, and the absence of effect during the $4^{\text {th }}$ Republic (column 4). Column 5 investigates the transmission mechanisms for the post-war period. When ideology and government size enter the same specification, this has the effect of rendering political ideology insignificant. In consequence, there seems to be some evidence that the effect of political ideology may run through public spending in the economy.

\footnotetext{
***Insert Table 8 here***
}

\subsection{Ideology and Government Size}


To investigate the transmission mechanism through public spending further, we explore the effect of ideology on government size for the whole of the period, 1873-2004. We use a specification based on PR (2011) and includes additional controls. This specification includes the lagged dependent variable, our main index of ideology, real GDP per capita from Maddison's website, income inequality from Atkinson (2005), the output gap given by the deviation of aggregate output from its trend value calculated from data from Maddison's website, the proportion of people between 15 and 64, the proportion of people over 65 and the openness of the economy. By allowing the error term to be autoregressive, we avoid the problem of spurious regressions due to non-stationarity of the variables, as illustrated by Ram (1987). This comes to estimating the relationship through a feasible least-squares procedure subject to the postulate of a first-order autoregressive process for the stochastic term. This hypothesis is verified because the estimates indicate that the autoregressive parameter is sizeable and statistically significant in all cases.

The results are presented in Table 9. Column 1 shows that right ideology does not explain government size in the total period 1873-2004. However, when interacting our ideology index with the dummies for the Republics, we notice that right ideology has a varying effect on government size, according to the different republics. Indeed, column 2 shows that ideology has a positive effect on government size during the $3^{\text {rd }}$ Republic, no statistically significant effect during the $4^{\text {th }}$ Republic, and a negative effect during the $5^{\text {th }}$ Republic. Column 3 indicates that the government size-enhancing effect of ideology is stable all through the $3^{\text {rd }}$ Republic, before and after the Ralliement in 1898. Finally, column 4 presents the regression results of the specification including the interaction between right ideology and real GDP per capita. While the previous specification does not provide a stable effect of ideology all along the observation period, this specification shows that the interaction term is negative and statistically significant at the $2 \%$ level. This can be interpreted by the following 
way: as the median voter gets richer, a move of its political ideology to the right of the average will lead him to demand smaller government size. On other words, as the median voter gets richer, a move of its political ideology to the left will lead him to demand bigger government size. This finding of this conditional effect of political ideology on government size is totally in line with PR $(2011 ; 2012)$ for recent periods.

To link these findings with the previous results of the growth regressions, we can now be confident that the voters' preferences in terms of government size have mediated the ideology-growth relationship only for recent periods. Indeed, our previous growth regressions showed that government size is not the channel that explains the positive growth effect of right ideology before World War II. However, we found that government size is indeed the channel that mediates the ideology-growth relationship afterwards. The findings of the government size regressions confirm the validity of this channel by providing evidence that right ideology decreases government size only for the post-war period and more generally as voters become richer. This demand of lower government size provoked by a median voter's move to the right explains the positive effect of right ideology on economic growth in the post-war period. The absence of effect on growth of ideology during the 4th Republic that we found prior can now be explained by the absence of effect of ideology on government size during this period. On the contrary, the growth enhancing effect of rightwing ideology in the $5^{\text {th }}$ Republic is explained by the fact the rightwing ideology reduced government size. In other words, after World War II, a move towards a rightwing ideology positively impacted growth only when this move entailed a decrease in the share on public spending.

\footnotetext{
***Insert Table 9 here***
}

\section{Conclusion}


This paper has asked whether differences in political ideology lead to differences in economic performance all along the French democratic experience. It is a first attempt to investigate this issue with time-series data, covering a period of more than one century. Surprisingly, our finding, regarding the effect of ideology on growth, is consistent with the few panel studies investigating the issue for post-1970 periods. We also provide evidence in line with the existing literature, regarding the transmission channel of government intervention, since right-wing governments experience less government involvement in the economy in the post-World War II period. However, this transmission mechanism should be considered carefully, as the influence of political ideology on government size is insufficient to explain its growth effect during the early stages of the French democratic experience. Our investigation left unanswered the transmission mechanisms between ideology and growth before World War II. The unexplained effect can stem from other policy channels, such as labour regulation, or individuals' social norms that could work directly on growth. Further research is required to investigate other possible transmission mechanisms, so as to distinguish the indirect effect mediated by policies and the direct effect of social norms.

However, our work differs from the rest of the literature investigating immutable growthenhancing policies, typically associated with the left and the right. Indeed, as documented by an important empirical literature, we assumed here that the same policy can have varying growth effects depending on the context, and therefore right(-left)wing parties can adopt different policies, to promote growth at different periods of time. This assumption led us to use a measurement of political ideology based on the historical right-left divide. We argued that such an ideology measure is suitable for the investigation of the growth effects of ideology, and provided robust results regarding the ideology-growth relationship. This method should be regarded as a complement to the increasing investigations based on manifesto data. 


\section{References}

Alesina, A., 1987. Macroeconomic Policy in a Two-party System as a Repeated Game. Harvard University Department of Economics.

Alesina, A., 1988. Macroeconomics and politics, in: NBER Macroeconomics Annual 1988, Volume 3. MIT Press, pp. 13-62.

Alesina, A., Roubini, N., Cohen, G.D., 1997. Political cycles and the macroeconomy. MIT press.

Aron, R., 1957. Espoir et peur du siècle. Paris.

Asselain, J.-C., Blancheton, B., 2005. Dynamique de l'ouverture internationale. Paradoxes, enjeux, éléments d'interprétation à partir du cas de la France. Economies et Sociétés (Serie'Histoire Economique Quantitative') 49-179.

Atkinson, A.B., 2005. Top Incomes in the UK over the 20th Century. Journal of the Royal Statistical Society: Series A (Statistics in Society) 168, 325-343.

Barro, R.J., 1991. Economic growth in a cross section of countries. The Quarterly Journal of Economics 106, 407-443.

Baudouin, J., 1990. Le «moment néo-libéral» du RPR: essai d'interprétation. Revue fran\ccaise de science politique 40, 830-844.

Beck, T., Clarke, G., Groff, A., Keefer, P., Walsh, P., 2001. New tools in comparative political economy: The Database of Political Institutions. The World Bank Economic Review 15, 165-176.

Bénabou, R., 2008. Ideology (Working Paper No. 13907). National Bureau of Economic Research.

Benabou, R., Ok, E.A., 1998. Social mobility and the demand for redistribution: the POUM hypothesis. National Bureau of Economic Research.

Beugelsdijk, S., De Groot, H.L., Van Schaik, A.B., 2004. Trust and economic growth: a robustness analysis. Oxford Economic Papers 56, 118-134.

Bjørnskov, C., 2005. Does political ideology affect economic growth? Public Choice 123, $133-146$.

Bjørnskov, C., 2008. The growth-inequality association: government ideology matters. Journal of Development Economics 87, 300-308.

Bjørnskov, C., Potrafke, N., 2011. Political ideology and economic freedom across Canadian provinces. Eastern Economic Journal 38, 143-166. 
Boy, D., Mayer, N., 1997. L'électeur a ses raisons. Presses de Sciences po.

Budge, I., Klingemann, H.-D., Volkens, A., Bara, J., Tanenbaum, E., 2001. Mapping policy preferences: Estimates for parties, electors, and governments 1945-1998. Oxford University Press, USA.

Buera, F.J., Monge-Naranjo, A., Primiceri, G.E., 2011. Learning the wealth of nations. Econometrica 79, 1-45.

Candar, G., Becker, J.-J., 2004. Histoire des gauches en France: L'héritage du XIXe siècle. La Découverte.

Cette, G., Kocoglu, Y., Mairesse, J., 2009. Productivity growth and levels in France, Japan, the United Kingdom and the United States in the Twentieth century. National Bureau of Economic Research.

Cusack, T., Iversen, T., Soskice, D., 2010. The coevolution of capitalism and political representation: Explaining the choice of electoral systems. American Political Science Review 104.

De Haan, J., Sturm, J.-E., 2000. On the relationship between economic freedom and economic growth. European Journal of Political Economy 16, 215-241.

Delorme, R., André, C., 1983. L'État et l'économie. Seuil.

Dolowitz, D., Marsh, D., 2006. Who learns what from whom: a review of the policy transfer literature. Political studies 44, 343-357.

Duclert, V., 2005. L'affaire Dreyfus et la Gauche. Poche/Sciences humaines et sociales 197214.

Durlauf, S.N., 2002. Symposium on social capital: introduction. The Economic Journal 112, F417-F418.

Durr, R.H., 1993. What moves policy sentiment? American Political Science Review 158170.

Evans, P., 1997. Government consumption and growth. Economic Inquiry 35, 209-217.

Facchini, F., Melki, M., 2013. Efficient government size: France in the 20th century. European Journal of Political Economy In Press.

Fair, R.C., 1970. The estimation of simultaneous equation models with lagged endogenous variables and first order serially correlated errors. Econometrica: Journal of the Econometric Society 507-516.

Fair, R.C., 1984. Specification, estimation, and analysis of macroeconometric models. Harvard University Press. 
Florio, M., Colautti, S., 2005. A logistic growth theory of public expenditures: A study of five countries over 100 years. Public Choice 122, 355-393.

Fridenson, P., 2005. Les gauches et l'économie. Poche/Sciences humaines et sociales 585599.

Gerber, A.S., Huber, G.A., 2009. Partisanship and Economic Behavior: Do Partisan Differences in Economic Forecasts Predict Real Economic Behavior? American Political Science Review 103, 407-426.

Goguel, F., 1946. La politique des partis sous la IIIe République. Éditions du Seuil.

Imbeau, L.M., Pétry, F., Lamari, M., 2001. Left-right party ideology and government policies: A meta-analysis. European Journal of Political Research 40, 1-29.

Jean-Pierre, L., 2000. Paul Vignaux; inspirateur de la «Deuxième gauche»: récits d'un exil franlccais aux Etats-Unis pendant la Seconde guerre mondiale. Matériaux pour l'histoire de notre temps $60,48-56$.

Jones, C.I., 1995. Time series tests of endogenous growth models. The Quarterly Journal of Economics 110, 495-525.

Kau, J.B., Rubin, P.H., 2002. The growth of government: sources and limits. Public Choice $113,389-402$.

Kocherlakota, N.R., Yi, K.-M., 1996. A simple time series test of endogenous vs. exogenous growth models: An application to the United States. The Review of Economics and Statistics $126-134$.

Kocherlakota, N.R., Yi, K.-M., 1997. Is there endogenous long-run growth? Evidence from the United States and the United Kingdom. Journal of Money, Credit, and Banking $235-262$.

Landau, D., 1983. Government expenditure and economic growth: a cross-country study. Southern Economic Journal 783-792.

Markussen, S., 2008. How the left prospers from prosperity. European Journal of Political Economy 24, 329-342.

Mittnik, S., Neumann, T., 2003. Time-Series Evidence on the Nonlinearity Hypothesis for Public Spending. Economic Inquiry 41, 565-573.

North, D.C., 1990. A transaction cost theory of politics. Journal of Theoretical Politics 2, 355-367.

North, D.C., 1998. Institutions, ideology, and economic performance. The Revolution in Development Economics 2, 95. 
Osterloh, S., 2012. Words speak louder than actions: The impact of politics on economic performance. Journal of Comparative Economics.

Perron, P., 1989. The great crash, the oil price shock, and the unit root hypothesis. Econometrica: Journal of the Econometric Society 1361-1401.

Pickering, A., Rockey, J., 2011. Ideology and the Growth of Government. Review of Economics and Statistics 93, 907-919.

Pickering, A.C., Rockey, J.C., 2012. Ideology and the Size of US State Government. Public Choice In Press.

Piketty, T., 1995. Social mobility and redistributive politics. The Quarterly journal of economics $110,551-584$.

Potrafke, N., 2011. Political cycles and economic performance in OECD countries: empirical evidence from 1951-2006. Public Choice 1-25.

Quinn, D.P., 2003. Capital account liberalization and financial globalization, 1890-1999: a synoptic view. International Journal of Finance \& Economics 8, 189-204.

Quinn, D.P., Toyoda, A.M., 2007. Ideology and voter preferences as determinants of financial globalization. American Journal of Political Science 51, 344-363.

Ram, R., 1986. Government size and economic growth: A new framework and some evidence from cross-section and time-series data. The American Economic Review 191-203.

Ram, R., 1987. Wagner's hypothesis in time-series and cross-section perspectives: Evidence from“ real” data for 115 countries. The Review of Economics and Statistics 194-204.

Rémond, R., 1963. La Droite en France-de la Premiere Restauration a la V. Republique 3, $1815-1940$.

Romp, W., De Haan, J., 2007. Public capital and economic growth: A critical survey. Perspektiven der Wirtschaftspolitik 8, 6-52.

Roy, A.G., 2009. Evidence on economic growth and government size. Applied Economics 41, $607-614$.

Siegfried, A., 1930. Tableau des partis en France. B. Grasset.

Snowberg, E., Wolfers, J., Zitzewitz, E., 2007. Partisan impacts on the economy: evidence from prediction markets and close elections. The Quarterly Journal of Economics 122, 807-829.

Stevenson, R.T., 2001. The economy and policy mood: a fundamental dynamic of democratic politics? American Journal of Political Science 620-633.

Stock, J.H., Yogo, M., 2005. Testing for weak instruments in linear IV regression. Chapter 5 in Identification and Inference in Econometric Models: Essays in Honor of Thomas J. 
Rothenberg, edited by DWK Andrews and JH Stock. Cambridge: Cambridge University Press.

Toutain, J.C., 1997. Le produit intérieur brut de la France. Histoire Economique Quantitative 24.

Zak, P.J., Knack, S., 2001. Trust and growth. The economic journal 111, 295-321. 
FIGURE 1

Evolution of the Ideology Index for France, the US and the UK, from 1869 to 2008

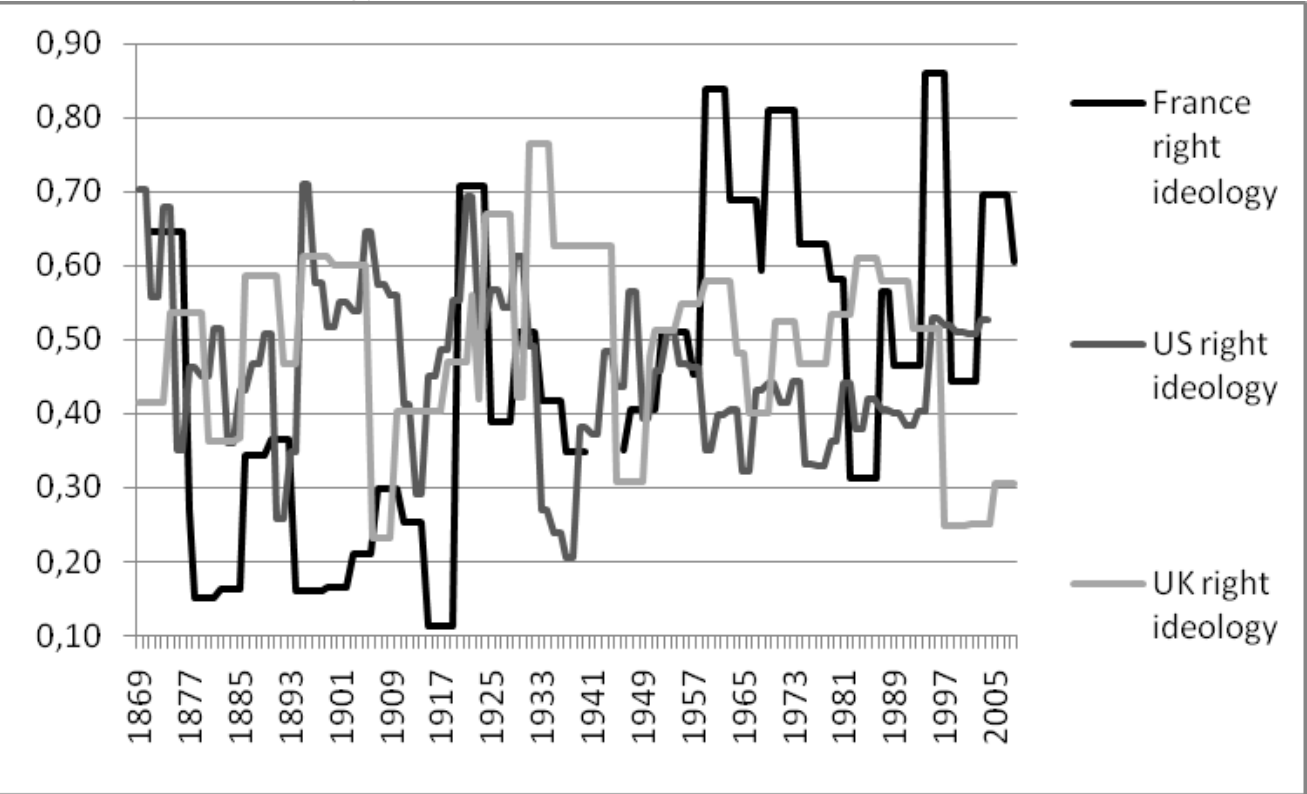


FIGURE 2

French real GDP growth rate (1869-2008)

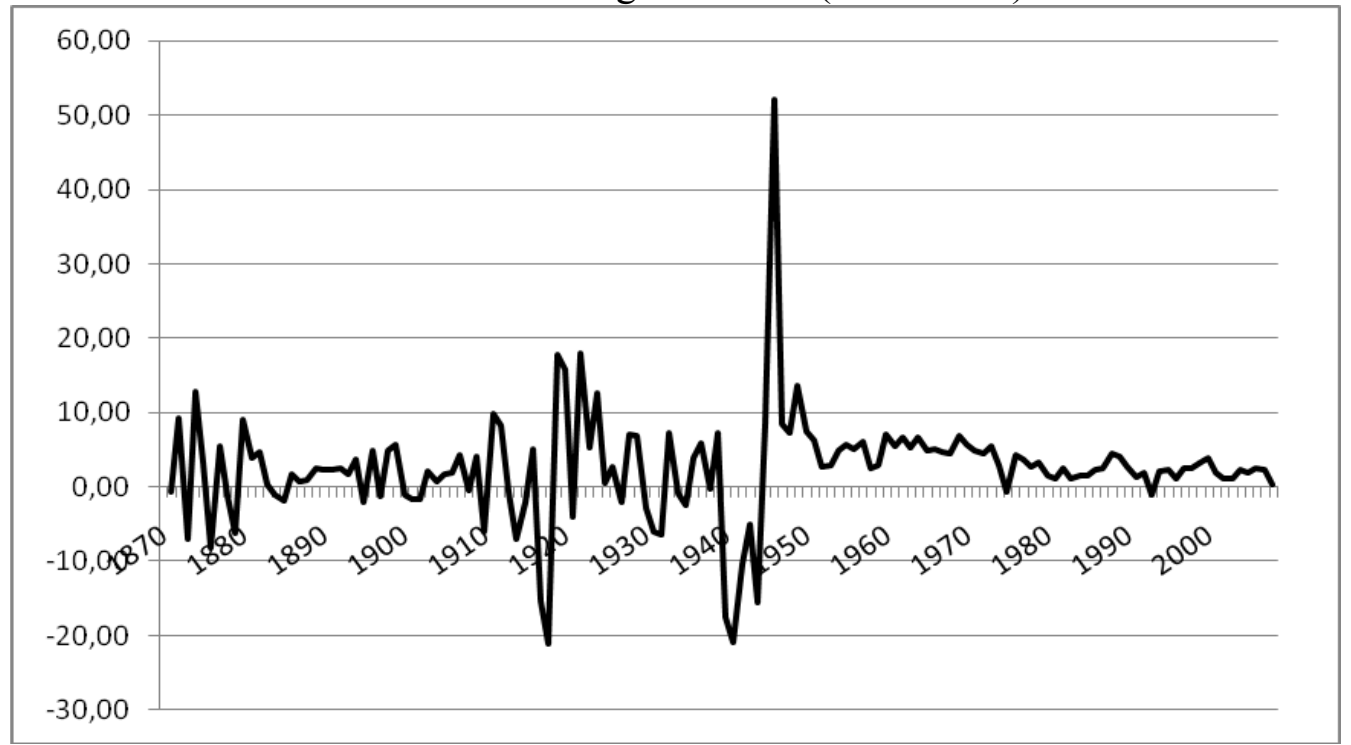

TABLE 1

Economic growth and political ideology, 1873-2004

\begin{tabular}{|c|c|c|c|c|}
\hline & \multicolumn{4}{|c|}{$\Delta$ (real GDP) 1873-2004 } \\
\hline & (1) & (2) & (3) & $(4)$ \\
\hline$\Delta$ (lag. real GDP) & $\begin{array}{l}0.121^{* *} \\
{[0.047]}\end{array}$ & $\begin{array}{l}0.105^{*} \\
{[0.054]}\end{array}$ & $\begin{array}{l}0.115^{* *} \\
{[0.051]}\end{array}$ & $\begin{array}{c}0.126^{* \star *} \\
{[0.045]}\end{array}$ \\
\hline$\Delta$ (investment) & $\begin{array}{c}0.240^{* * *} \\
{[0.039]}\end{array}$ & $\begin{array}{c}0.236^{\star \star *} \\
{[0.038]}\end{array}$ & $\begin{array}{c}0.241^{* * *} \\
{[0.038]}\end{array}$ & $\begin{array}{c}0.226^{* * *} \\
{[0.037]}\end{array}$ \\
\hline$\Delta$ (labor) & $\begin{array}{c}0.289 \\
{[0.309]}\end{array}$ & $\begin{array}{c}0.357 \\
{[0.317]}\end{array}$ & $\begin{array}{l}0.2941 \\
{[0.324]}\end{array}$ & $\begin{array}{c}0.159 \\
{[0.268]}\end{array}$ \\
\hline$\Delta$ (openness) & $\begin{array}{c}0.286^{\star * *} \\
{[0.105]}\end{array}$ & $\begin{array}{l}0.270^{* *} \\
{[0.112]}\end{array}$ & $\begin{array}{l}0.282^{\star *} \\
{[0.110]}\end{array}$ & $\begin{array}{c}0.284^{* * *} \\
{[0.095]}\end{array}$ \\
\hline$\Delta$ (oil price) & $\begin{array}{l}-0.008 \\
{[0.012]}\end{array}$ & $\begin{array}{c}-0.009 \\
{[0.011]}\end{array}$ & $\begin{array}{c}-0.009 \\
{[0.012]}\end{array}$ & $\begin{array}{l}-0.009 \\
{[0.010]}\end{array}$ \\
\hline right ideology & - & $\begin{array}{l}0.011^{* *} \\
{[0.004]}\end{array}$ & - & - \\
\hline right dummy & - & - & $\begin{array}{c}0.005 \\
{[0.006]}\end{array}$ & - \\
\hline right ideology average & - & - & - & $\begin{array}{c}0.028^{\star \star *} \\
{[0.007]}\end{array}$ \\
\hline constant & $\begin{array}{c}0.025^{\star \star \star} \\
{[0.002]}\end{array}$ & $\begin{array}{c}0.035^{\star \star \star} \\
{[0.005]}\end{array}$ & $\begin{array}{c}0.015 \\
{[0.017]}\end{array}$ & $\begin{array}{c}0.098^{\star * *} \\
{[0.028]}\end{array}$ \\
\hline $\operatorname{adj} . R^{2}$ & 0.675 & 0.693 & 0.677 & 0.717 \\
\hline Observations & 118 & 118 & 118 & 118 \\
\hline
\end{tabular}

Notes: (1) The observation sample excludes the war years. (2) White-corrected standard errors in brackets. * significant at $10 \%$; ** significant at $5 \%$; ** significant at $1 \%$. (3) We control for the outliers with annual dummy variables. A Jarque-Bear test is systematically performed to make sure of the normality of the error terms. (4) A Box-Pierce test is performed to make sure of the absence of serial auto-correlation. 
TABLE 2

Economic growth and political ideology, 1873-2004. Robustness Checks.

\begin{tabular}{lccc}
\hline & \multicolumn{1}{c}{$\Delta($ real GDP $)$} & $1873-2004$ & $(3)$ \\
\cline { 2 - 4 } & $(1)$ & 0.070 & 0.043 \\
& $0.105^{*}$ & {$[0.047]$} & $0.052]$ \\
rlag. real GDP) & {$[0.055]$} & $0.016^{* *}$ & $0.018^{* * *}$ \\
right ideology & $0.015^{\star *}$ & {$[0.006]$} & {$[0.006]$} \\
government size & {$[0.007]$} & $-0.039^{* * *}$ & $-0.031^{* *}$ \\
& -0.006 & {$[0.012]$} & {$[0.013]$} \\
post WWII dummy & {$[0.005]$} & $0.039^{* * *}$ & - \\
republic dummy & - & {$[0.014]$} & yes \\
adj. $\mathrm{R}^{2}$ & & - & 0.744 \\
Observations & - & 0.732 & 118 \\
\hline
\end{tabular}

Notes: (1) The specifications estimated includes the independent variables of the baseline growth regression: the first differences of investment, of labour, of openness and of oil price, a constant and annual dummy variables for the outliers. (2) The observation sample excludes the war years. (3) White-corrected standard errors in brackets. ${ }^{*}$ significant at $10 \%$; ** significant at 5\%; *** significant at 1\%. (4) A Box-Pierce test is performed to make sure of the absence of serial auto-correlation. 
TABLE 3

Economic growth and political ideology, 1873-2004. Robustness Checks.

\begin{tabular}{|c|c|c|c|c|c|c|c|c|c|c|c|}
\hline & \multicolumn{11}{|c|}{$\Delta$ (real GDP) 1873-2004 } \\
\hline & $(1)$ & $(2)$ & (3) & $(4)$ & $(5)$ & $(6)$ & $(7)$ & (8) & $(9)$ & $(10)$ & $(11)$ \\
\hline right ideology & $\begin{array}{c}0.018^{* \star \star} \\
{[0.006]}\end{array}$ & $\begin{array}{c}0.018^{* * *} \\
{[0.006]}\end{array}$ & $\begin{array}{c}0.018^{\star \star \star} \\
{[0.006]}\end{array}$ & $\begin{array}{c}0.018^{\star * *} \\
{[0.006]}\end{array}$ & $\begin{array}{c}0.018^{* \star \star} \\
{[0.006]}\end{array}$ & $\begin{array}{c}0.018^{* \star \star} \\
{[0.006]}\end{array}$ & $\begin{array}{c}0.019^{* \star *} \\
{[0.006]}\end{array}$ & $\begin{array}{l}0.014^{\star \star} \\
{[0.007]}\end{array}$ & $\begin{array}{c}0.019^{\star \star *} \\
{[0.006]}\end{array}$ & $\begin{array}{c}0.019^{* \star *} \\
{[0.006]}\end{array}$ & $\begin{array}{c}0.018^{* * *} \\
{[0.006]}\end{array}$ \\
\hline elecloral year & $\begin{array}{c}0.003 \\
{[0.005]}\end{array}$ & - & - & - & - & - & - & - & - & - & - \\
\hline$\Delta($ age $)$ & - & $\begin{array}{c}0.246 \\
{[0.421]}\end{array}$ & - & - & - & - & - & - & - & - & - \\
\hline$\Delta($ prop15_64) & - & - & $\begin{array}{c}-0.102 \\
{[0.121]}\end{array}$ & - & - & - & - & - & - & - & - \\
\hline$\Delta($ prop65) & - & - & - & $\begin{array}{c}0.221 \\
{[0.207]}\end{array}$ & - & - & - & - & - & - & - \\
\hline$\Delta$ (life expectancy) & - & - & - & - & $\begin{array}{l}-0.125 \\
{[0.482]}\end{array}$ & - & - & - & - & - & - \\
\hline$\Delta$ (tertiary enrollment) & - & - & - & - & - & $\begin{array}{l}0.011^{* *} \\
{[0.004]}\end{array}$ & - & - & - & - & - \\
\hline$\Delta$ (social conflict) & - & - & - & - & - & - & $\begin{array}{l}6.93 \mathrm{E}-10 \\
{[6.50 \mathrm{E}-10]}\end{array}$ & - & - & - & - \\
\hline$\Delta$ (immigration) & - & - & - & - & - & - & - & $\begin{array}{c}0.120 \\
{[0.119]}\end{array}$ & - & - & - \\
\hline$\Delta$ (self-employment) & - & - & - & - & - & - & - & - & $\begin{array}{l}0.001^{* * *} \\
{[0.0002]}\end{array}$ & - & - \\
\hline inflation & - & - & - & - & - & - & - & - & - & $\begin{array}{l}0.0007^{* *} \\
{[0.0003]}\end{array}$ & - \\
\hline$\Delta$ (unemployment) & - & - & - & - & - & - & - & - & - & - & $\begin{array}{l}-0.005 \\
{[0.015]}\end{array}$ \\
\hline $\operatorname{adj} . R^{2}$ & 0.745 & 0.749 & 0.745 & 0.746 & 0.744 & 0.745 & 0.747 & 0.747 & 0.751 & 0.760 & 0.744 \\
\hline Observations & 118 & 118 & 118 & 118 & 118 & 118 & 118 & 118 & 118 & 118 & 118 \\
\hline
\end{tabular}

Notes: (1) The specifications estimated includes the independent variables of the baseline growth regression: the first differences of the lagged real GDP, of investment, of labour, of openness and of oil price, a constant, Republic dummy and dummies for the outliers. (2) The observation sample excludes the war years. (3) White-corrected standard errors in brackets. * significant at 10\%; ** significant at 5\%;*** significant at $1 \%$. (4) A Box-Pierce test is performed to make sure of the absence of serial auto-correlation. 
TABLE 4

Economic growth and political ideology, 1873-2004. Robustness Checks.

\begin{tabular}{|c|c|c|c|}
\hline & \multicolumn{3}{|c|}{$\Delta$ (real GDP) 1873-2004 } \\
\hline & $(1)$ & $(2)$ & $(3)$ \\
\hline$\Delta$ (lag. real GDP) & $\begin{array}{c}0.036 \\
{[0.054]}\end{array}$ & $\begin{array}{c}0.035 \\
{[0.055]}\end{array}$ & $\begin{array}{c}0.021 \\
{[0.051]}\end{array}$ \\
\hline government size & - & - & $\begin{array}{c}-0.036^{* * *} \\
{[0.001]}\end{array}$ \\
\hline right ideology ${ }^{\star} 3$ rd republic & $\begin{array}{c}0.014^{\star * *} \\
{[0.004]}\end{array}$ & - & $\begin{array}{c}0.034^{* * *} \\
{[0.007]}\end{array}$ \\
\hline right ideology*dummy1873_1898 & - & $\begin{array}{c}0.014^{\star * *} \\
{[0.005]}\end{array}$ & - \\
\hline right ideology*dummy1899_1939 & - & $\begin{array}{l}0.013^{* *} \\
{[0.005]}\end{array}$ & - \\
\hline right ideology ${ }^{*} 4$ th republic & $\begin{array}{l}-0.015 \\
{[0.010]}\end{array}$ & $\begin{array}{l}-0.016 \\
{[0.010]}\end{array}$ & $\begin{array}{l}-0.015^{*} \\
{[0.009]}\end{array}$ \\
\hline right ideology ${ }^{\star} 5$ th republic & $\begin{array}{l}0.018^{* *} \\
{[0.008]}\end{array}$ & $\begin{array}{l}0.018^{* *} \\
{[0.007]}\end{array}$ & $\begin{array}{c}0.002 \\
{[0.008]}\end{array}$ \\
\hline $\operatorname{adj} . R^{2}$ & 0.774 & 0.776 & 0.801 \\
\hline Observations & 118 & 118 & 118 \\
\hline
\end{tabular}

Notes: (1) The specifications estimated includes the independent variables of the baseline growth regression: the first differences of investment, of labour, of openness and of oil price, a constant and annual dummy variables for the outliers. (2) The observation sample excludes the war years. (3) White-corrected standard errors in brackets. * significant at 10\%; ** significant at 5\%; *** significant at 1\%. (4) A Box-Pierce test is performed to make sure of the absence of serial auto-correlation.

TABLE 5

French political ideology and US-UK political ideology, 1873-2004: first-stage of the 2SLS estimates

\begin{tabular}{lc}
\hline & right ideology $\mathrm{t}_{\mathrm{t}}$ 1873-2004 \\
\cline { 2 - 2 } & $2 \mathrm{SLS}$ \\
US-UK ideology $\mathrm{t}_{\mathrm{t}-2}$ & (First Stage) \\
\hline US-UK ideology $\mathrm{t}_{\mathrm{t}-3}$ & $0.230^{\star *}$ \\
& {$[0.110]$} \\
F-Stat (First Stage) & $-0.181^{\star *}$ \\
adj. R & {$[0.089]$} \\
Observations & 117.886 \\
\hline
\end{tabular}

Notes: (1) The specifications estimated include the independent variables of the baseline growth regression: the first differences of the lagged real GDP, investment, labour, openness and oil price, a constant along with the lagged dependant variable and the annual dummy variables for the outliers. (2) The observation sample excludes the war years. (3) White-corrected standard errors in brackets. * significant at $10 \%$; ** significant at 5\%; *** significant at 1\%. (4) A Box-Pierce test is performed to make sure of the absence of serial auto-correlation. 
TABLE 6

Economic growth and political ideology, 1873-2004: OLS and 2SLS second-stage estimates $\Delta$ (real GDP) 1873-2004

\begin{tabular}{lcc} 
& \multicolumn{2}{c}{$\Delta$ (real GDP) $1873-2004$} \\
\cline { 2 - 3 } & OLS & $(2)$ \\
\hline$\Delta$ (lag. real GDP) & $0.110^{* \star *}$ & 2SLS (Second Stage) \\
right ideology & {$[0.041]$} & $0.109^{* \star *}$ \\
& $0.011^{* \star *}$ & {$[0.041]$} \\
Prob (J-statistic) & {$[0.004]$} & $0.012^{\star \star *}$ \\
adj. $R^{2}$ & - & {$[0.004]$} \\
Observations & 0.692 & 0.266 \\
\hline
\end{tabular}

Notes: (1) The specifications estimated include the independent variables of the baseline growth regression: the first differences of investment, of labour, openness and oil price, a constant and annual dummy variables for the outliers. (2) The instruments used in column 2 are US-UK ideology $\mathrm{t}_{\mathrm{t}-2}$ and US-UK ideology $\mathrm{t}_{\mathrm{t}-3}$. (3) The observation sample excludes the war years. (4) White-corrected standard errors in brackets. * significant at $10 \%$; ** significant at 5\%;*** significant at 1\%. (5) A Box-Pierce test is performed to make sure of the absence of serial auto-correlation.

TABLE 7

Economic growth and political ideology, subperiod 1873-1938

\begin{tabular}{lcc}
\hline & \multicolumn{3}{c}{$\Delta$ (real GDP) $1873-1938$} \\
\cline { 2 - 3 } & $(1)$ & $(2)$ \\
\hline$\Delta$ (lag. real GDP) & -0.080 & -0.083 \\
right ideology & {$[0.077]$} & {$[0.080]$} \\
& $0.041^{\star \star \star}$ & $0.041^{\star \star \star}$ \\
government size & {$[0.009]$} & {$[0.010]$} \\
& - & 0.002 \\
adj. $\mathrm{R}^{2}$ & 0.768 & {$[0.017]$} \\
Observations & 60 & 0.7687 \\
\hline
\end{tabular}

Notes: (1) The specifications estimated include the independent variables of the baseline growth regression: the first differences of investment, labour, openness, a constant and annual dummy variables for the outliers. (2) The observation sample excludes the war years. (3) White-corrected standard errors in brackets. * significant at $10 \%$;* significant at $5 \%$; *** significant at $1 \%$. (4) A Box-Pierce test is performed to make sure of the absence of serial auto-correlation. 
TABLE 8

Economic growth and political ideology, subperiod 1947-2004

\begin{tabular}{|c|c|c|c|c|c|}
\hline & & $\Delta(r$ & P) 1947 & & \\
\hline & $(1)$ & $(2)$ & (3) & $(4)$ & (5) \\
\hline$\Delta$ (lag. real GDP) & $\begin{array}{c}0.151^{\star * *} \\
{[0.041]}\end{array}$ & $\begin{array}{c}0.168^{\star * *} \\
{[0.041]}\end{array}$ & $\begin{array}{c}0.167^{\star * *} \\
{[0.048]}\end{array}$ & $\begin{array}{c}0.136^{* \star \star} \\
{[0.041]}\end{array}$ & $\begin{array}{c}0.046 \\
{[0.030]}\end{array}$ \\
\hline right ideology & $\begin{array}{l}0.017^{* *} \\
{[0.007]}\end{array}$ & - & - & - & $\begin{array}{l}0.0005 \\
{[0.005]}\end{array}$ \\
\hline right dummy & - & $\begin{array}{l}0.008^{* *} \\
{[0.004]}\end{array}$ & - & - & - \\
\hline right ideology manifesto & - & - & $\begin{array}{c}-2.42 \mathrm{E} \\
{[0.0003]}\end{array}$ & - & - \\
\hline right ideology ${ }^{*} 4$ th republic & - & - & - & $\begin{array}{c}-0.007 \\
{[0.008]}\end{array}$ & - \\
\hline right ideology ${ }^{*} 5$ th republic & - & - & - & $\begin{array}{l}0.018^{* *} \\
{[0.007]}\end{array}$ & - \\
\hline government size & - & - & - & - & $\begin{array}{c}-0.095^{* * *} \\
{[0.012]}\end{array}$ \\
\hline republic dummy & yes & yes & yes & - & yes \\
\hline adj. $R^{2}$ & 0.714 & 0.705 & 0.689 & 0.721 & 0.878 \\
\hline Observations & 58 & 58 & 51 & 58 & 58 \\
\hline
\end{tabular}

Notes: (1) The specifications estimated include the independent variables of the baseline growth regression: the first differences of investment, labour, openness and oil price, a constant and annual dummy variables for the outliers. (2) White-corrected standard errors in brackets. * significant at $10 \%$; ** significant at 5\%; *** significant at 1\%. (3) A Box-Pierce test is performed to make sure of the absence of serial auto-correlation.

TABLE 9

Government size and political ideology, 1873-2004

\begin{tabular}{|c|c|c|c|c|}
\hline & \multicolumn{4}{|c|}{ government size 1873-2004 } \\
\hline & (1) & $(2)$ & (3) & (4) \\
\hline lag. government size & $\begin{array}{c}0.788^{\star * \star} \\
{[0.037]}\end{array}$ & $\begin{array}{c}0.739^{* * *} \\
{[0.036]}\end{array}$ & $\begin{array}{c}0.739^{* * *} \\
{[0.036]}\end{array}$ & $\begin{array}{c}0.757^{\star * *} \\
{[0.038]}\end{array}$ \\
\hline real GDP per capita & $\begin{array}{c}0.054 \\
{[0.040]}\end{array}$ & $\begin{array}{c}0.098^{*} \\
{[0.055]}\end{array}$ & $\begin{array}{c}0.100 \\
{[0.061]}\end{array}$ & $\begin{array}{l}0.082^{\star *} \\
{[0.041]}\end{array}$ \\
\hline right ideology & $\begin{array}{c}0.012 \\
{[0.847]}\end{array}$ & - & - & $\begin{array}{l}0.093^{* *} \\
{[0.044]}\end{array}$ \\
\hline real GDP per capita*right ideology & - & - & - & $\begin{array}{c}-0.044^{* *} \\
{[0.017]}\end{array}$ \\
\hline right ideology ${ }^{*} 3$ rd republic & - & $\begin{array}{l}0.040^{* *} \\
{[0.015]}\end{array}$ & - & - \\
\hline right ideology*dummy1873_1898 & - & - & $\begin{array}{l}0.040^{* *} \\
{[0.017]}\end{array}$ & - \\
\hline right ideology*dummy1899_1939 & - & - & $\begin{array}{l}0.040^{* *} \\
{[0.016]}\end{array}$ & - \\
\hline right ideology ${ }^{*} 4$ th republic & - & $\begin{array}{l}-0.038 \\
{[0.026]}\end{array}$ & $\begin{array}{l}-0.039 \\
{[0.027]}\end{array}$ & - \\
\hline right ideology ${ }^{*} 5$ th republic & - & $\begin{array}{c}-0.045^{* * *} \\
{[0.014]}\end{array}$ & $\begin{array}{c}-0.044^{* * *} \\
{[0.014]}\end{array}$ & - \\
\hline adj. $R^{2}$ & 0.993 & 0.994 & 0.994 & 0.994 \\
\hline Observations & 118 & 118 & 118 & 118 \\
\hline
\end{tabular}

Notes: (1) The specification estimated includes important controls not reported in the table: a constant, prop15_64, prop65, openness, output gap and annual dummy variables for the outliers. Income inequality is excluded from the reported estimations as it does not reach significance. (2) White-corrected standard errors in brackets. * significant at $10 \%$; ** significant at $5 \%$; *** significant at $1 \%$. (3) A Jarque-Bear test is systematically performed to make sure of the normality of the error terms. (4) A Box-Pierce test is performed to make sure of the absence of serial auto-correlation. 


\section{APPENDIX}

\section{TABLE 10}

Description and source of variables

\begin{tabular}{|c|c|c|}
\hline Name & Defintion & Source \\
\hline age & Average age of the total population & INED: Institut National d'Etudes Démographiques \\
\hline elecloral year & dummy variable coded 1 for the years of election and 0 otherwise & - \\
\hline \multirow[t]{2}{*}{ government size } & percentage of total public spending (central state, social protection and local public authorities) & André and Delorme (1987) \\
\hline & in total GDP & National Institute of Statistics and Economic Studies (INSEE) \\
\hline immigration & percentage of foreigners in the total population & National Accounts - INSEE \\
\hline inflation & inflation rate & Thomas Piketty website \\
\hline investment & gross Domestic capital formation as percentage of GDP at current prices. & Maddison's website \\
\hline labor & Average annual hours actually worked & Cette et al. (2009); OECD \\
\hline life expectancy & life expectancy at birth & INSEE; INED \\
\hline oil price & crude oil price barrel. Real Constant 2005 dollars & http://www.ioga.com/Special/crudeoil Hist.htp \\
\hline openness & percentage of the sum of importations and exportations in total GDP & Asselain and Blancheton (2005); World Bank \\
\hline output gap & $\begin{array}{l}\text { deviation of aggregate output from its trend value in percentage. The variable is derived from } \\
\text { the GDP growth rate using the Hodrick-Prescott filter. }\end{array}$ & own calculation \\
\hline post WWII dummy & dummy variable coded 0 before 1945 and 1 afterwards & - \\
\hline prop15_64 & percentage of population aged $14<$ age $<65$ & Mitchell (2007) \\
\hline prop65 & percentage of population aged 65 and over & Mitchell (2007) \\
\hline $\begin{array}{l}\text { real GDP } \\
\text { right dummy }\end{array}$ & $\begin{array}{l}\text { annual gross domestic product in million } 1990 \text { international Geary-Khamis dollars } \\
\text { dummy coded } 1 \text { for the years when the rightwing deputies have the majority in the Lower } \\
\text { Chamber of the French Parliament }\end{array}$ & $\begin{array}{l}\text { Maddison's website. Historical Statistics of the World Economy. } \\
\text { see: right ideology }\end{array}$ \\
\hline right ideology & $\begin{array}{l}\text { percentage of the right-wing deputies in the Lower Chamber of the French Parliament } \\
\text { (Chamber of Deputies for the 3rd and } 4 \text { th Republic and National Assembly for the } 5 \text { th } \\
\text { Republic) excluding French overseas departments and territories }\end{array}$ & $\begin{array}{l}\text { Website of the French National Assembly; Laurent de Boissieu's } \\
\text { website; Goguel (1946); Rémond (1963) }\end{array}$ \\
\hline right ideology average & 10-year moving average of right ideology & see: right ideology \\
\hline right ideology manifesto & median voter ideology position by weighting party ideologies according to their vote received & Manifesto Reasearch group (MRG) (Budge et al., 2001) \\
\hline self employment & $\begin{array}{l}\text { percentage of self-employment including people working on their own account without help } \\
\text { except for family workers }\end{array}$ & Flora et al. (1987); International Labour Organization (ILO) \\
\hline social conflict & number of individual non-worked days & National Accounts - INSEE \\
\hline tertiary enrollment & percentage of the number of students in universities in the total population & Mithcell (2007) \\
\hline unemployment & unemployment rate & Villa (1994); INSEE \\
\hline US-UK ideology & $\begin{array}{l}\text { mean of the indexes of ideology for the US and the UK. The indexes are given by the } \\
\text { percentage of Republican and Conservative (and allies) deputies in the Lower Chamber of the } \\
\text { US House of Representatives and the UK House of Commons, respectively. }\end{array}$ & $\begin{array}{l}\text { United States Census Bureau (2012); } \\
\text { http://www.election.demon.co.uk/; Craig (1989) }\end{array}$ \\
\hline 3rd republic & dummy variable coded 1 for the period $1871-1940$ and 0 otherwise & - \\
\hline 4th republic & dummy variable coded 1 for the period $1946-1958$ and 0 otherwise & - \\
\hline 5th republic & dummy variable coded 1 for the period $1959-2008$ and 0 otherwise & - \\
\hline
\end{tabular}

boissieu.htm 
TABLE 11

Falsification test for French political ideology and US-UK political ideology, 1873-2004

\begin{tabular}{|c|c|c|c|c|c|}
\hline & \multicolumn{5}{|c|}{ right ideology $y_{t} 1873-2004$} \\
\hline & $(1)$ & $(2)$ & (3) & (4) & $(5)$ \\
\hline US-UK ideology $y_{t}$ & $\begin{array}{c}-0.024 \\
{[0.066]}\end{array}$ & - & - & - & - \\
\hline US-UK ideology $\mathrm{y}_{t+1}$ & - & $\begin{array}{l}-0.065 \\
{[0.064]}\end{array}$ & - & - & - \\
\hline US-UK ideology $\mathrm{y}_{\mathrm{t}+2}$ & - & - & $\begin{array}{c}-0.018 \\
{[0.064]}\end{array}$ & - & - \\
\hline US-UK ideology $\mathrm{y}_{\mathrm{t}+3}$ & - & - & - & $\begin{array}{c}-0.019 \\
{[0.067]}\end{array}$ & - \\
\hline US-UK ideology $\mathrm{y}_{\mathrm{t}+4}$ & - & - & - & - & $\begin{array}{l}-0.053 \\
{[0.070]}\end{array}$ \\
\hline $\operatorname{adj} . R^{2}$ & 0.814 & 0.814 & 0.820 & 0.820 & 0.821 \\
\hline Observations & 118 & 118 & 118 & 118 & 118 \\
\hline
\end{tabular}

Notes: (1) The specifications estimated include the independent variables of the baseline growth regression: the first differences of the lagged real GDP, investment, labour, openness and oil price, a constant along with the lagged dependant variable and the annual dummy variables for the outliers. (2) The observation sample excludes the war years. (3) White-corrected standard errors in brackets. * significant at $10 \%$; ** significant at 5\%; *** significant at 1\%. (4) A Box-Pierce test is performed to make sure of the absence of serial auto-correlation. 